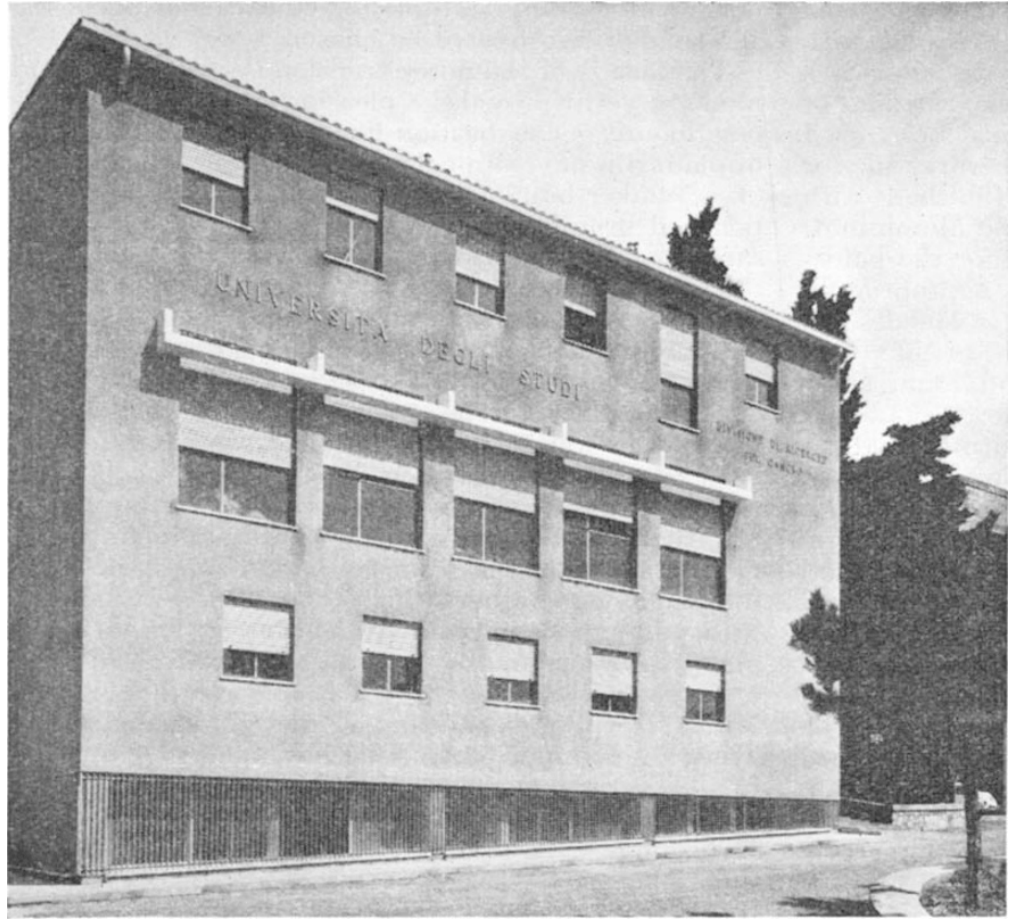

Fig. 1. New Extension of the Division of Cancer Research, University of Perugia

In recent years, much effort has been transferred to the study of causation, behaviour and evolution of mammary tumours in inbred mice. The origins, nature, fate and hormonal control of the hyperplastic alveolar nodules in the mammary glands of virgin and breeding animals carrying the milk factor have been analysed in a series of papers. After the discovery of a new kind of pre-malignant change, the plaque, in hybrid animals, various inbred strains of mice normally bred were investigated to determine the occurrence of plaques. These have been found in two of the three strains investigated. In connexion with these experiments, an analysis of responsiveness and progression of mammary tumours of inbred mice was carried out, which led to the detection of the existence of strain differences in the biological and morphological characters of neoplasms. Finally, a recent extension of these investigations has shown that the strain differences found might be due to differences in the properties of the respective milk factors.

A new field of investigation, cytology, opened at the Division of

colony and laboratories for research in biology and pathology. Later, in the years 1956 and 1957, a programme of improvement was completed with the aid of grants and contributions.

During recent years, investigations have been carried out in the Division by various groups of scientists on different aspects of cancer research. Work on the spreading of metastases in human and experimental tumours has been described in a series of papers dealing with the various facets of the problem. A valuable contribution to the conflicting problems of the morphological precursors of human breast cancer was made by the staff of the Division of Cancer Research working as a unit. In the initial phase, different types of mammary cancer, arising from different lesions, and characterized by a different age at onset, retiological pattern and morphology were detected and classified. It was then shown that the frequency and the latency period were also different for each of these types of cancer. On this basis, an attempt was made to determine the order of importance of the respective morphological precursors; this is still regarded as a useful factor for prognosis. Cancer Research with the conversion of a spontaneous mammary tumour into an ascites tumour. Work on the mitotic rate and chromosomal pattern of this ascites tumour is now in progress.

Recently, it was demonstrated that isoniazid, a drug very widely used in the management of tuberculosis, is carcinogenic for the lungs of $B A L B / c$ mice. Due to its practical importance, this field of investigation has been rapidly extended in order to see whether isoniazid is carcinogenic to other species of animals, whether it is carcinogenic in itself or through some of its metabolites, and how this carcinogenic action may be prevented.

Since its foundation, the Division of Cancer Research has encouraged, within the limits of its facilities, visits of qualified scientists from foreign countries, in order to exchange information and ideas on the work in progress. A large number of such visitors have come during recent years. Several of them delivered lectures. For others, small seminars were organized with the staff. Other visiting scientists have spent several months working at the Division of Cancer Research with members of the staff, in fields of common interest.

\title{
THE INTERNATIONAL FEDERATION FOR DOCUMENTATION
}

$T$

HE twenty-seventh conference of the International Federation for Documentation was held at Caxton Hall, London, during September 6-16. The Federation has its headquarters at The Hague, and its work on many different problems of documentation is carried on mainly through correspondence, committees and meetings of the Executive
Bureau and a General Assembly held each year in a different country. The large, unrestricted, conference gatherings take place only every three or four years and this was the first to be held in England since 1938. It was attended by more than 500 delegates coming from 38 countries and from all five continents. Aslib, as the British representative 
body in the Federation, was responsible for the arrangements.

The earlier part of the conference, that is, during September 6-11, was devoted to meetings of committees, the Executive Bureau, and the General Assembly with a special session on September 9 to consider present-day systems and trends in automatic documentation such as the use of electronic computers and research into the possibilities of mechanical translation. Excursions to Oxford and Cambridge were arranged for September 10.

During the second week of the conference, an exhibition of new processes and experimental work in documentation was open, and included a device for the automatic identification of printed numerals demonstrated by Dr. M. B. Clowes and Mr. J. R. Parks of the National Physical Laboratory.

The official opening of the full conference took place on September 12 when the Baroness Wootton of Abinger, deputizing for Lord Hailsham, Minister for Science, gave the opening address. The chairman, Dr. Burton W. Adkinson, head of the Office of Science Information, U.S. National Science Foundation, referred to the great loss to the Federation through the recent death of Fritz Donker Duyvis. His passing had been "the quiet closing of a door on an age", the age of the pioneers of documentation such as Otlet and La Fontaine, and of the devoted amateurs who followed them such as "D. D." who, for more than two decades, was the embodiment of the International Federation for Documentation. After this tribute to the late secretary-general of the Federation, the meeting heard four papers describing recent developments in documentation. These were presented by Dr. K. Schneider (Germany), who described the use of electric typewriters operated by punched cards; Mr. A. C. van Schaik (Netherlands), who showed that advantages could come through bibliographical co-operation within a country; Mr. C. W. Cleverdon (United Kingdom), who outlined the work of the Aslib Cranfield investigation into the efficiency of indexing systems, and Mr. Karl F. Heumann (United States), who presented Verner W. Clapp's summary of recent important progress in documentation in the United States. In the evening. delegates attended a reception given by the ViceChancellor of the University of London and Mrs. Noble at the Senate House.

The morning sessions of September 13 dealt with scientific and technical information under the chairmanship of Dr. M. A. T. Rogers, research controller, Imperial Chemical Industries, Ltd, deputizing for Dr. T. E. Allibone, who was indisposed. Papers were contributed by Mr. R. G. l'Hermite (France), Dr. A. Moore (United States), who dealt particularly with the problem of information in the pharmaceutical indus. try, and Dr. Y. Niwa, who described the history and growth of the Japan Information Centre of Science and Technology and similar services in his country.

The afternoon session was presided over by Mr. G. Deurinck, of the Fondation Industrie-Université pour le Perfectionnement des Dirigeants d'Enterprises, Belgium. The papers covered the documentation of management (Prof. R. W. Revans, United Kingdom, and Prof. J. L. Mey, Netherlands), and the use of information for economic planning (Mr. K. Havliček, Czechoslovakia). In the evening delegates were invited to a reception given by Imperial Chemical Industries, Ltd., at Imperial Chemical House, Millbank.

The efficient use of information was the theme of the morning session for September 14 when the chair was again taken by Dr. Burton W. Adkinson. Mr. R. E. McBurney described the work of the Canadian Technical Information Service of the National Research Council. Mr. K. Klintoe, director of the Danish Technical Information Service, spoke on productivity in information service, Mr. William $\mathrm{T}$. Knox gave an interesting talk on the use by some United States companies of senior scientists or engineers as information research workers, and Mr. J. de Laclémandière (France) set out his views on information and the 'law of least effort'. The afternoon was left free for visits and other activities and in the evening a reception was held by H.M. Government in the unique setting of the King's Library, British Museum, when Lord and Lady Hailsham received the guests.

The final public session and the official closure of the conference took place on the afternoon of September 15, with Dr. Alexander King, president of the Federation, in the chair. The General Assembly this year had been attended by representatives of twenty-four member countries and by observers from several other regions. Dr. King welcomed the presence of Miss Hilda S. Lindstedt, formerly librarian of the Royal Technical University, Stockholm, and now an honorary member of the Federation. Dr. King went on to say that the decision to break away from tradition and to hold the 1960 meetings at Rio de Janeiro had had important consequences for the International Federation for Documentation, including some changes in constitutional procedure. In future, presidents would be elected a year in advance of the date on which they would take office and retiring presidents would serve an additional year as members of the Executive Bureau; all this made for continuity.

Dr. King announced that Dr. Burton W. Adkinson would succeed him as president in 1962 . Vicepresidents were working appointments chosen on a regional basis. The vice-presidents for Western Europe were now Miss Barbara Kyle (United Kingdom), Dr. Z. Paulo (Portugal), Dr. W. Schurmeyer (Germany) and Prof. E. Wegelius (Finland). East European vice-presidents were Dr. L. Janzky (Hungary) and Prof. A. I. Mikhailov (U.S.S.R.). Dr. S. R. Ranganathan (India) had retired and his place had not yet been filled, but Far Eastern representation was in the capable hands of Prof. $H$. Ootuka (Japan). For the Americas, Mr. K. F. Heumann (United States) would replace Dr. Burton Adkinson, now president-elect, and Prof. Lydia Sambaquy (Brazil) would continue in office.

Turning to future conferences, Dr. King announced that the meeting for 1962 would be at The Hague. It was hoped that a meeting in one of the Asian countries could be arranged for 1963 or 1964, and the United States had issued an invitation to hold the next unrestricted conference in Washington in 1965.

Dr. King then dealt with the committees, the secretariats of which were now each located in different member countries. Mr. E. Ohman (Sweden) had been appointed the first full-time officer of the Universal Decimal Classification at The Hague. The training of personnel for carrying out documentation was being actively investigated under Prof. Majewski at Warsaw, a newly constituted committee to consider the theory of classification would be based in Denmark, responsibility for linguistic problems had been accepted by the Netherlands, and mechanized documentation was the special concern of the German 
section. A new ad hoc Committee had been set up to give an impartial study to the future of the Universal Decimal Classification.

For the closing moments of the conference Dr. Burton Adkinson took over the chair and voiced the thanks of the delegates to the representatives of the host country, and in particular to Aslib, for the organization of the conference and for the accompanying programme of visits and entertainment.

E. M. R. Ditmas

\title{
X-RAY MICRO-ANALYSIS
}

\begin{abstract}
T IST $177 / 2$, recently issued by the Cambridge Instrument Co., Ltd., is an illustrated booklet* giving a comprehensive description of the Company's 'Microscan' X-ray analyser which is now in production. The technique of X-ray micro-analysis consists of focusing an electron beam, normally accelerated from 0 to $50 \mathrm{kV}$., on to a region of the surface of the specimen, approximately $I \mu$ in diameter and rather less in depth, and analysing spectroscopically the resulting $X$-rays excited from the specimen. $\mathbf{R}$. Castaing, in 1951, published details of the first practical instrument that could be described as an 'emission' micro-analyser, but Castaing's instrument, in common with similar instruments developed independently by others, used a static electron probe; it was thus limited to carrying out only point-by-point microanalyses on parts of the sample surface previously selected under an optical microscope. The Cambridge instrument incorporates a deflexion system to control the electron probe, and in addition to static point-topoint micro-analyses it can also be used for scanning a maximum area of about $\frac{1}{2} \times \frac{1}{2} \mathrm{~mm}^{2}$ on the sample surface. It is based on the instrument originally designed by Dr. D. A. Melford and colleagues at the Tube Investments Research Laboratories in collaboration with Dr. V. E. Cosslett and Dr. P. Duncumb, who were responsible for the prototype developed at the Cavendish Laboratory, University of Cambridge.

In the booklet the arrangement, constructional details and functioning of the analyser are clearly set out, together with photographs of parts of the instrument and of results obtained with the instrument. The analyser consists of four separately standing sections-the electrical supply unit, the main console,

* The Microscan X-ray Analyser, Pp. 32 (London: Cambridge Instrument Co., Ltd., 1961).
\end{abstract}

and three racks occupied mainly by scanning, counting and display electronic equipment, respectively. In the main console are housed the vacuum system consisting principally of a 2 -in. oil diffusion pump backed by a rotary pump; the electron-optical system; the specimen chamber on which the electronoptical system is mounted and which is designed to allow from outside the maximum possible manipulation of the specimen which is itself under high vacuum. Sixteen positions are provided on the table and the table can be rotated to bring any one of the positions under either the electron beam or the optical microscope; the binocular optical microscope for conventional optical examination of the specimen for comparison with the electron image; and the semifocusing X-ray spectrometer of a special and simplified design, containing three curved, rotatable, lithium fluoride crystals and two interchangeable detectors, one a sealed-off proportional counter for the detection of hard radiations and the other a flow proportional counter for soft radiations.

The technique of X-ray micro-analysis has so far been successfully applied to investigating the microstructure of both metals and minerals, and although the 'Microscan' was designed primarily for metallurgical work it can be used for substances other than metals. By providing both X-ray and electron pictures of small surface regions, the analyser is invaluable as a metallurgical tool, and the examples of its application to the examination of various alloys and inclusions in steel which are discussed and illustrated in the booklet show clearly its advantages. Its main limitation, in common with other similar instruments, is its inability at present to detect the soft X-rays from specimens consisting of elements of atomic number less than twelve.

\section{DISTRIBUTION OF INTENSITY AMONG VARIOUS ULTRASONIC DIFFRACTION ORDERS}

\author{
By DR. C. RAGHUPATHI RAO \\ Department of Physics, Nizam College, Hyderabad
}

\begin{abstract}
T THE generalized theory of Raman and Nath gives very complicated expressions which, with certain restrictions, have been modified by $\mathrm{Nath}^{1}$ to get closed expressions for intengities of ultrasonic diffraction orders. The intensity of the supersonic field is assumed to be not strong enough to excite the second and higher orders and solving the differencedifferential equation obtained in the generalized theory, the following expressions for the intensities of the first and central zero orders have been obtained for normal incidence:
\end{abstract}

$$
\begin{gathered}
I_{1}=\frac{4}{\rho^{2}+8} \sin ^{2}\left\{\frac{\sqrt{\rho^{2}+8}}{4} \xi\right\} \\
I_{0}=1-\frac{8}{\rho^{2}+8} \sin ^{2}\left\{\frac{\sqrt{\rho^{2}+8}}{4} \xi\right\} \\
\text { where } \quad \rho=\frac{\lambda^{2}}{\omega \omega_{0} \lambda^{* 2}} \text { and } \xi=\frac{2 \pi \omega L}{\lambda}
\end{gathered}
$$

